\title{
THE IMPACT OF PARTIAL SWEETENER SUBSTITUTION ON PHYSICOCHEMICAL, TEXTURAL AND SENSORY PROPERTIES OF BISCUITS
}

\author{
Mehmet Güldane $^{1 *}$, Emine Nur Herken ${ }^{2}$ \\ ${ }^{1}$ Program of Laboratory Technology, Vocational School of Pamukova, Sakarya University of Applied Sciences, \\ Sakarya, Turkey \\ ${ }^{2}$ Department of Food Engineering, Pamukkale University, Denizli, Turkey
}

Received / Geliş: 02.11.2021; Accepted / Kabul: 21.01.2022; Published online / Online bask1: 01.02.2022

Güldane, M., Herken, E.N. (2022). The impact of partial sweetener substitution on physicochemical, textural and sensory properties of biscuits. GIDA (2022) 47 (1) 66-77 doi: 10.15237/gida.GD21138.

Güldane, M., Herken, E.N. (2022). Kısmi tatlandırıcı ikamesinin bisküvilerin fizikokimyasal, tekstürel ve duyusal özelliklerine etkisi. GIDA (2022) 47 (1) 66-77 doi: 10.15237/gida.GD21138.

\begin{abstract}
The aim of the present work was to study the physicochemical, textural and sensory properties of biscuits prepared by replacing sucrose with rare sugar (D-psicose) and/or polyols (sorbitol, xylitol) at $25 \%$ or $50 \%$. The results showed that increasing D-psicose replacement resulted in lower moisture content, darker and less yellow, and thicker biscuits. However, opposite effects were observed in polyol substitute biscuits. The texture of the biscuits was also significantly affected by the sweeteners. After two months of storage, the hardness values had significantly decreased in the samples with $50 \%$ alternative sweeteners $(P<0.05)$. The sensory evaluation of the biscuits containing natural sweeteners was close to that of sucrose $(100 \%)$. In conclusion, D-psicose and polyols generally had opposite effects on biscuit characteristics. Therefore, it was found that the samples with similar/better properties to/than the control could be prepared by replacing sucrose with D-psicose (25\%) and polyol(s) (25\%).
\end{abstract}

Keywords: D-psicose, hardness, polyol, sucrose, xylitol

\section{KISMİ TATLANDIRICI İKAMESİNIN BİSKÜVILLERİN FİZIKKOKIMYYSAL, TEKSTÜREL VE DUYUSAL ÖZELLİKLERINNE ETKİSİ}

\section{ÖZ}

Bu çalışmanın amacı, sakkarozun nadir şeker (D-psikoz) ve/veya poliollerle (sorbitol, ksilitol) \%25 veya $\% 50$ oranında değiştirilmesiyle hazırlanan bisküvilerin fizikokimyasal, tekstürel ve duyusal özelliklerini belirlemektir. Sonuçlar incelendiğinde, D-psikoz ikamesinin artmasıyla bisküvilerde nem içeriğinin azaldığı, daha koyu renkte olan daha kalın bisküvilerin elde edildiği görüldü. Bununla birlikte, bisküvilerde poliol ikamesinin artmasıyla nem içeriği artarak parlaklık $(L)$ ve kırmızılık (a) değerleri azalmıştır. Pişmiş bisküvilerin tekstürü de tatlandırıcı ikamesinden önemli ölçüde etkilenmiştir. İki aylık depolama sonunda \%50 alternatif tatlandırıcılı örneklerde sertlik değerleri önemli ölçüde azalmıştır $(P<0.05)$. Alternatif tatlandırıcılar içeren bisküvilerin duyusal değerlendirmesi kontrole yakındır. Sonuç olarak, D-psikoz ve poliollerin araştırılan bisküvi özelliklerine etkileri genel olarak birbirinin tersi olmuştur. Bu nedenle, sakkarozun D-psikoz (\%25) ve polioller (\%25) ile değiştirilmesiyle kontrole benzer veya kontrolden daha iyi özelliklere sahip numunelerin hazırlanabileceği belirlendi.

Anahtar kelimeler: D-psikoz, sertlik, poliol, sakkaroz, ksilitol

* Corresponding author / Yazışmalardan sorumlu yazar

(1): mehmetguldane@subu.edu.tr

(ग): (+90) 2646160800

且: (+90) 2646160014

Mehmet Güldane; ORCID no: 0000-0001-7321-0496

Emine Nur Herken; ORCID no: 0000-0003-1553-8025 


\section{INTRODUCTION}

Biscuits, consumed all over the world, are made with a mixture of sugar, fat and wheat flour as the main ingredients. The various interactions between these basic ingredients significantly affect the quality characteristics of ready-to-eat biscuits (Chevallier et al., 2000). Sucrose, as a traditional sweetener, is used in biscuit formulation to improve physicochemical, textural and sensory properties (Gallagher et al., 2003; Lin et al., 2010). Globally, about 140 million tonnes of sucrose are produced from sugar beet and sugar cane annually, and most of it is used in foods such as bakery products, breakfast cereals, desserts and beverages (Fasahat et al., 2021).

Obesity, which is closely associated with excessive sugar and fat consumption, is considered one of the major health problems in the world (Taylor et al., 2008; Karp et al., 2016). In particular, the prevalence of childhood obesity has been increased significantly over the past decade (Schroeder et al., 2021), and 13\% of the adult population worldwide has been classified as obese (Edwards et al., 2016). Prevalent chronic diseases such as cardiovascular disease, cholesterol, diabetes and dental problems are associated with extreme sugar consumption (Granström et al., 2004; Pareyt et al., 2009; Laguna et al., 2013). Due to the proven effects of obesity on human health, reduction of sugar content in foods has been recommended by WHO (2014) ( Struck et al., 2014; Kweon et al., 2016). Concerns about the adverse health effects of excessive sucrose consumption have led to the emergence of alternative sweeteners, which are absorbed more slowly from the intestine and contain less energy (Ghosh and Sudha, 2012; Mooradian et al., 2017). These sweeteners can be partially substituted for sucrose to produce lower calorie and healthier baked goods (Drewnowski et al., 1998).

The alternative sweeteners, which are basically classified as artificial and natural sugars, are proposed to reduce the energy content of baked goods and address specific nutritional problems. Studies show that the use of artificial sweeteners in the production of biscuits leads to quality problems (Davis, 1995). Not only the sensory properties such as appearance, texture, taste and mouthfeel, but also the textural and rheological properties are negatively affected by the replacement of sucrose with these sweeteners (Mariotti and Alamprese, 2012). On the other hand, the natural sweeteners, called "bulk sweeteners" or "sugar replacers", are widely used to meet specific texture, volume and sweetness requirements of the baked product. To this end, polyols such as xylitol, lactitol, sorbitol, mannitol, isomalt, erythritol, hydrogenated starch hydrolysate, and hydrogenated glucose syrup, as well as rare sugars (i.e., D-psicose and D-tagatose) may be substituted for sugars in the product formulation (Kroger et al., 2006). Moreover, the synergistic interaction of sucrose with natural sweeteners may reduce the production costs and improve the quality of the final product (Mooradian et al., 2017).

In this study, the effect of partial substitution of sucrose with alternative sweeteners on biscuit quality characteristics was investigated. Accordingly, this research aimed to demonstrate the evaluability of sorbitol, xylitol and/or dpsicose as alternative sweeteners to meet the textural properties of biscuit dough and the physicochemical, textural and organoleptic properties of ready-to-eat biscuits.

\section{MATERIALS AND METHODS \\ Materials}

Commercial wheat flour, sodium bicarbonate, fine granulated sugar, iodized table salt, and shortening were purchased from a local grocery (Denizli, Turkey) and the emulsifier (glyceryl monostearate, GMS 90) was purchased from Huzur Chemistry Ltd. (Istanbul, Turkey), Dpsicose (CAS No.: 551-68-8) was purchased from JinZhongYan New Material Technology Co. Ltd. (China). Sorbitol (pure powder) was purchased from Bereket Chemistry Ltd. (Istanbul, Turkey) and xylitol (Smart Sweet Xylitol Powder) was procured from Homestead Market (Monticello, USA). All chemicals used were of analytical grade.

\section{Biscuits Preparation}

A Total of 10 model biscuit samples, including the control (Sample 1) were prepared according to a 
recipe as described in AACC Method 10-54 (AACC, 1990). D-psicose, sorbitol and xylitol were replaced with sucrose at $25 \%$ or $50 \%$ (weight basis). The recipes for the model biscuits are shown in Table 1. To obtain a biscuit dough, the sweetener(s) (40 g), wheat flour (100 g), shortening (40 g), baking powder (1.5 g), salt (1 g) and emulsifier $(0.5 \mathrm{~g})$ were homogeneously mixed in a mixing vessel and then $20 \mathrm{ml}$ of tap water was added. After 15 min of kneading, the dough was allowed to rest at $25{ }^{\circ} \mathrm{C}$ for $20 \mathrm{~min}$. The rested dough was rolled into a dough with a diameter of $30 \mathrm{~mm}$ and a thickness of $5 \mathrm{~mm}$ and then baked in a preheated conventional oven (ASL Machine, Turkey) at $180{ }^{\circ} \mathrm{C}$ for 10 minutes. The baked biscuits were allowed to cool at room temperature for $20 \mathrm{~min}$ and then placed in polypropylene bags and stored at room temperature until analysis.

Table 1. Model biscuit formulations.

\begin{tabular}{lcccccccccc}
\hline \multirow{2}{*}{ Ingredients } & \multicolumn{10}{c}{ Biscuit formulations (g) } \\
\cline { 2 - 11 } & 1 & 2 & 3 & 4 & 5 & 6 & 7 & 8 & 9 & 10 \\
\hline Powdered sugar & 40 & 20 & 20 & 20 & 20 & 20 & 20 & 30 & 30 & 30 \\
D-psicose & - & 20 & - & - & 10 & 10 & - & 10 & - & - \\
Sorbitol & - & - & 20 & - & 10 & - & 10 & - & 10 & - \\
Xylitol & - & - & - & 20 & - & 10 & 10 & - & - & 10 \\
All-purpose flour & 100 & 100 & 100 & 100 & 100 & 100 & 100 & 100 & 100 & 100 \\
Shortening & 40 & 40 & 40 & 40 & 40 & 40 & 40 & 40 & 40 & 40 \\
Water (ml) & 20 & 20 & 20 & 20 & 20 & 20 & 20 & 20 & 20 & 20 \\
Sodium bicarbonate & 1.5 & 1.5 & 1.5 & 1.5 & 1.5 & 1.5 & 1.5 & 1.5 & 1.5 & 15 \\
Salt & 1 & 1 & 1 & 1 & 1 & 1 & 1 & 1 & 1 & 1 \\
Emulsifier & 0.5 & 0.5 & 0.5 & 0.5 & 0.5 & 0.5 & 0.5 & 0.5 & 0.5 & 0.5 \\
\hline
\end{tabular}

\section{Proximate composition}

The dry matter, ash, crude fat and crude protein contents of the biscuits were determined according to the official methods of the American Association of Cereal Chemistry (AACC, 1990). The moisture content and total inorganic matter content were analyzed at $105{ }^{\circ} \mathrm{C}$ and $550{ }^{\circ} \mathrm{C}$, respectively. The crude fat was determined by the Soxhlet method. The total nitrogen content was determined by the micro-Kjeldahl method, and protein content was calculated using a conversion factor $(\mathrm{N}=5.70)$.

In vitro protein digestibility (IVPD) analysis was performed according to the method proposed by Hsu et al. (1977). Five milliliters of the multienzyme solution containing trypsin, chymotrypsin, and peptidase at the ratio of 1.6:3.1:1.3 were kept under chilly conditions and the $\mathrm{pH}$ of the solution was adjusted to 8.0 with $0.1 \mathrm{~N} \mathrm{HCI} / \mathrm{NaOH}$. The $\mathrm{pH}$ of the $50 \mathrm{ml}$ aqueous solution of the sample kept in a water bath at 37 ${ }^{\circ} \mathrm{C}$ was set to 8.0 , and then $5 \mathrm{ml}$ of the multienzyme solution was mixed into this solution. Immediately thereafter, the change in
$\mathrm{pH}$ of the suspension was recorded for $10 \mathrm{~min}$ was $\left(\mathrm{pH}_{10 \mathrm{~min}}\right)$. The percentage IVPD values of the biscuits were determined according to Equation 1.

$\operatorname{IVPD}(\%)=210.4-18.1 \mathrm{pH}_{10 \mathrm{~min}}$

\section{Physical properties}

The following procedures were used to determine the diameter, thickness, spread ratio, and weight of the baked biscuits. The diameter and thickness of the samples were measured using a vernier caliper. A diameter of three different biscuits was determined, then all samples were rotated $90^{\circ}$ and a new diameter value was recorded. The average of the two measurements was evaluated as the diameter of the final biscuits. Height measurements were made according to the method of Zoulias et al. (2000). To measure height, three biscuits from different batches were stacked on top of each other. An average value from four different measurements was taken as the sample thickness. The spread ratio was calculated by dividing the biscuit diameter by the height. The weight of the samples was determined by measuring the average weight of three biscuits. 
The $\mathrm{L}, \mathrm{a}$, and $\mathrm{b}$ values of the model biscuits were determined using a Hunter Lab colorimeter (Reston, VA, USA). The instrument was calibrated using standard calibration tiles prior to color measurement. The values of lightness (L), yellowness (b), and redness (a) of the samples were recorded.

\section{Texture analysis}

Texture profile analysis (TPA) of the dough and baked biscuits were performed according to a modified method proposed by Herken et al. (2017), and experiments were performed using a Brookfield CT30 texture analyzer. The dough was formed into samples of $3 \mathrm{~cm}$ diameter and $5 \mathrm{~mm}$ thickness. In the compression test, a cylindrical probe with a diameter of $4 \mathrm{~cm}$ and the pre-/posttest speed of $0.5 \mathrm{~mm} / \mathrm{s}$ was applied to the dough with a force of $6 \mathrm{mN}$ to characterise the forcedeformation curves. Then, the parameters such as hardness $(\mathrm{N})$ and adhesiveness $(\mathrm{N})$ were determined.

The textural characterization of the samples stored in polypropylene ziplock bags at room temperature was measured on the 1st, 3rd, 7th, 15th, 30th and 60th day after biscuit production. In the compression test, a cutting probe with a sharp-blade (three-point bend) was pressed on the biscuit sample at a pre-/post-test speed of 0.5 $\mathrm{mm} / \mathrm{s}$ with a force of $6 \mathrm{mN}$ to measure the textural properties of the biscuits. The hardness of the model biscuits was determined by the maximum force $(\mathrm{N})$ required to break a biscuit sample.

\section{Sensory analysis}

Sensory evaluation of the biscuits was performed by 30 trained panelists composed of students and academic staff from the Department of Food Engineering, Pamukkale University, Turkey. Organoleptic properties were evaluated using a 5point hedonic scale $(1=$ extremely dislike; $2=$ dislike; $3=$ moderately like; $4=$ like; $5=$ extremely like). Sensory analysis were performed within 12 hours of baking the biscuits. Samples were coded with 3-digit random numbers, presented to panelists in random order along with a cup containing $200 \mathrm{ml}$ of water, and sensory analysis of color, flavor, sweetness, texture, and overall acceptability was rated (Gül et al., 2013).

\section{Statistical analysis}

Experimental results are reported as mean \pm SD (standard deviation) of at least three parallel experiments and measurements. Results were analyzed using the statistics program SPSS 17.0 (SPSS Inc., Chicago, IL, USA). Analysis of variance (ANOVA) was performed and Tukey's test was conducted to determine the significant differences between the mean values $(P<0.05)$.

\section{RESULTS AND DISCUSSION \\ Proximate composition}

The proximate composition of the biscuits with different formulations is shown in Table 2. The replacement of sucrose with polyols (sorbitol and xylitol) at 50\% significantly increased the moisture content of the biscuits compared to the control biscuit with $100 \%$ sucrose $(P<0.05)$. Among the sweeteners, sorbitol $(50 \%)$ significantly increased the moisture content of the biscuits. This was attributed to the fact that sorbitol retains moisture and does not dry out the biscuits (Ghosh and Sudha, 2012). The results obtained in this study are in agreement with Ho and Pulsawat (2020) who stated that sorbitol is more hygroscopic than sucrose. Majeed et al., (2018) reported that polyols like sorbitol and xylitol help to retain moisture in biscuits depending on their hydrophilic properties. On the other hand, it was observed that the moisture content of biscuits tended to decrease with the substitution of D-psicose with sucrose. This might be related to the lower water binding capacity of D-psicose compared to sucrose (Pocan et al., 2019).

The total ash content in biscuits provides information on the amount of inorganic matter (Ho and Pulsawat, 2020). The ash content of the biscuit samples varied from $1.25 \%$ to $1.32 \%$ (Table 2). Among the biscuits, the control sample contained the lowest ash content, while a general increase in ash content was observed with the replacement of other sweeteners. However, this increase was not statistically significant $(\mathrm{P}>0.05)$. Similar results were found by Lin et al. (2010) in Danish cookies substituted with erythritol (50\%) 
and Vatankhah et al. (2015) in biscuits containing stevioside $(50 \%)$. In contrast, Ho and Pulsawat (2020) reported that cookies substituted with sorbitol $(50 \%)$ had lower mineral content than the control samples. This situation may be related to differences in sugar production technologies. In addition, partial substitution of sucrose with Dpsicose, sorbitol and xylitol had no effect on the protein and fat content of the biscuits.

The IVPD values of the biscuits varied from $70.68 \%$ to $73.97 \%$ (Table 2). Protein digestibility increased with increasing polyol addition. Biscuits with sorbitol or xylitol $(50 \%)$ contained significantly higher amount of digestible protein compared to the control sample. The use of polyols had no effect on total protein content, but resulted in a significant improvement in digestible protein content. Substitution with D-psicose had no positive effect on protein digestibility. The lowest protein digestibility was found in biscuits with D-psicose $(50 \%)$. This situation may be related to the negative effects of sweeteners involved in Maillard and caramelization reactions on protein digestibility properties. When evaluating the results, it was possible to prepare biscuits with a proximate composition close to the control by replacing sucrose in certain proportions with D-psicose and sorbitol in the formulation (Sample 5).

Table 2. Proximate composition of biscuits prepared with different sweeteners.

\begin{tabular}{lccccc}
\hline Sample $^{*}$ & Moisture (\%) & Ash (\%) & Protein (\%) & Fat (\%) & IVPD (\%) \\
\hline 1 & $2.91 \pm 0.23^{(\mathrm{bc})}$ & $1.25 \pm 0.03^{(\mathrm{a})}$ & $5.58 \pm 0.16^{(\mathrm{a})}$ & $23.73 \pm 0.09^{(\mathrm{a})}$ & $70.97 \pm 0.17(\mathrm{bc})$ \\
2 & $2.38 \pm 0.02^{(\mathrm{d})}$ & $1.29 \pm 0.19^{(\mathrm{a})}$ & $5.57 \pm 0.07^{(\mathrm{a})}$ & $23.74 \pm 0.02^{(\mathrm{a})}$ & $70.68 \pm 0.63^{(\mathrm{c})}$ \\
3 & $3.10 \pm 0.43^{(\mathrm{ab})}$ & $1.26 \pm 0.05^{(\mathrm{a})}$ & $5.63 \pm 0.02^{(\mathrm{a})}$ & $23.53 \pm 0.01^{(\mathrm{a})}$ & $72.89 \pm 1.20^{(\mathrm{ab})}$ \\
4 & $3.33 \pm 0.28^{(\mathrm{a})}$ & $1.28 \pm 0.02^{(\mathrm{a})}$ & $5.63 \pm 0.02^{(\mathrm{a})}$ & $23.94 \pm 0.20^{(\mathrm{a})}$ & $73.97 \pm 0.40^{(\mathrm{a})}$ \\
5 & $2.98 \pm 0.36^{(\mathrm{abc})}$ & $1.30 \pm 0.04^{(\mathrm{a})}$ & $5.65 \pm 0.03^{(\mathrm{a})}$ & $23.85 \pm 0.37^{(\mathrm{a})}$ & $70.79 \pm 0.62^{(\mathrm{bc})}$ \\
6 & $2.68 \pm 0.02^{(\mathrm{cd})}$ & $1.28 \pm 0.08^{(\mathrm{a})}$ & $5.64 \pm 0.01^{(\mathrm{a})}$ & $24.18 \pm 0.65^{(\mathrm{a})}$ & $70.83 \pm 0.22^{(\mathrm{c})}$ \\
7 & $3.05 \pm 0.04^{(\mathrm{abc})}$ & $1.27 \pm 0.02^{(\mathrm{a})}$ & $5.63 \pm 0.03^{(\mathrm{a})}$ & $24.70 \pm 1.29^{(\mathrm{a})}$ & $72.59 \pm 1.59^{(\mathrm{abc})}$ \\
8 & $2.68 \pm 0.09^{(\mathrm{cd})}$ & $1.31 \pm 0.01^{(\mathrm{a})}$ & $5.59 \pm 0.01^{(\mathrm{a})}$ & $23.95 \pm 0.15^{(\mathrm{a})}$ & $70.72 \pm 1.20^{(\mathrm{c})}$ \\
9 & $3.03 \pm 0.07^{(\mathrm{abc})}$ & $1.29 \pm 0.01^{(\mathrm{a})}$ & $5.63 \pm 0.02^{(\mathrm{a})}$ & $23.83 \pm 0.08^{(\mathrm{a})}$ & $71.09 \pm 0.52^{(\mathrm{bc})}$ \\
10 & $2.95 \pm 0.05^{(\mathrm{bc})}$ & $1.32 \pm 0.01^{(\mathrm{a})}$ & $5.62 \pm 0.04^{(\mathrm{a})}$ & $23.85 \pm 0.19^{(\mathrm{a})}$ & $71.06 \pm 0.64^{(\mathrm{bc})}$ \\
\hline
\end{tabular}

Different small superscripts indicate significant differences $(P<0.05)$ between biscuit samples

\section{Physical properties of biscuits}

The diameter, height, spread ratio, weight, and color values (Hunter $\mathrm{L}, \mathrm{a}, \mathrm{b}$ ) of the biscuit samples are shown in Table 3. The use of D-psicose (50\%) in biscuit production affected the diameter values $(P<0.05)$. The diameters of the control sample and the other samples were not statistically different, and these samples had the largest diameter $(P<0.05)$. Taylor et al. (2008) found that the dissolution behaviour of sugar in biscuit dough affects spreadability during baking. The biscuit becomes spreadable when the sugar dissolves slowly, and it does not spreadable when the sugar dissolves to a limited extent. When the results were examined, it was found that the use of polyols (sorbitol or xylitol) or D-psicose (25\%) instead of sucrose did not affect the spreadability of the biscuits during baking. Similar results were found by Zoulias et al. (2000) for the replacement of maltitol (35\%). In contrast, Taylor et al. (2008) (using tagatose substitution (25\%) in cookies) and Karp et al. (2016) (using stevia substitution (20\%) in muffins) reported that sweetener substitution for sucrose caused a reduction in the diameter of baked goods.

The height values $(8.97 \pm 0.17$ and $8.42 \pm 0.07$, respectively) of biscuits with high D-psicose or sorbitol substitution $(50 \%)$ differed from the control sample $(8.57 \pm 0.25)$, and these differences were statistically significant $(P<0.05)$. The height of biscuits varied according to the gluten development. The ability of sugars to bind water to gluten proteins affects the height of biscuits (Taylor et al., 2008). Sorbitol is more hygroscopic than D-psicose and xylitol. Therefore, the gluten development was limited and the height of biscuits increased less. On the other hand, due to 
the less hygroscopicitiy of D-psicose, the height increased more because there was enough water for gluten development.

The biscuits containing D-psicose (25\%) and sorbitol $(25 \%)$ had the same spread ratio as the control sample. Further spreading was observed in samples containing sorbitol $(50 \%)$ and xylitol $(25 \%)$ / sorbitol $(25 \%)$. The lowest diffusion ratio was obtained for the samples containing Dpsicose $(50 \%)$. Spreadability of biscuits is mainly determined by dough viscosity (Miller \& Hoseney, 1997). Sorbitol had a viscosity lowering effect by retaining more water in the dough structure. Diffusion ratio values increased with increasing sorbitol content. In addition, the dissolution of sugar during baking contributes to the spreading of the samples. Since D-psicose was completely dissolved before baking, it contributed to the spread ratio only to a limited extent. Taylor et al. (2008) reported that lower spread ratio values were obtained for fructose-substituted biscuits compared to the control.

There was no statistical difference between the weight (baking loss) values of the biscuit samples. The replacement of sucrose with $50 \%$ or $25 \%$ polyol and/or rare sugar had no effect on biscuit weight $(\mathrm{p}>0.05)$. Among the samples, the biscuits with $50 \%$ polyol replacement had the highest weight. Higher polyol replacement resulted in lower water evaporation in the biscuits as the more hygroscopic sugars in the formulation may result in better water retention, making water less likely to evaporate. In contrast, the D-psicose substituted biscuits had the lowest weight (the lowest water retention during baking) because Dpsicose is less hygroscopic.

The Hunter L, a, b values of the biscuits are summarised in Table 3. The $\mathrm{L}(+)$ values indicate the lightness of the samples. The a $(+)$ values represent redness, and the $\mathrm{b}(+)$ values represent yellowness. Replacement of sucrose with Dpsicose at certain ratios $(25 \%$ or $50 \%)$ resulted in a significant decrease in the lightness of the biscuits. Moreover, it was observed that with increasing D-psicose replacement ratio in the samples, redness increased while yellowness decreased. Similar results were obtained by Pocan et al. (2019) who studied gelatin-based soft candies with D-psicose substitutes. As the polyol replacement ratio in the biscuits increased, the lightness (L) and yellowness (b) increased and the redness (a) decreased. Lin et al. (2010) found that increasing the erythritol replacement ratio $(25 \%$, $50 \%, 75 \%$, and $100 \%$ ) resulted in a gradual increase in the $\mathrm{L}$ values of the cookies. Similar results were reported by Ho and Pulsawat (2020), Majeed et al. (2018) and Zoulias et al. (2000). The colour values obtained as a function of the changes in the biscuit formulation were related to caramelization and Maillard reactions (Karp et al., 2016). The colour development was better in samples containing the reducing sugar (Dpsicose) than those containing non-reducing polyols. In addition, it was found that the colour properties of the samples in which $\mathrm{D}$-psicose and polyols were equally substituted were similar to the control sample. For example, the values of $\mathrm{L}$

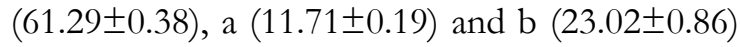
of the sample containing D-psicose $(25 \%)$ and sorbitol $(25 \%)$ were close to the sample prepared with $100 \%$ sucrose $(62.85 \pm 0.83,10.98 \pm 0.31$ and $23.23 \pm 0.01$, respectively). In general, the biscuits with improved physical properties, similar to the control sample, were obtained by using equal amounts of rare sugar (D-psicose) and polyols (sorbitol and xylitol) instead of half sucrose in the biscuit formulation.

\section{Textural properties of biscuit dough}

TPA was performed to objectively evaluate the effect of sweetener substitution on biscuit dough. The results of texture analysis were interpreted in terms of hardness $(\mathrm{N})$ and adhesiveness $(\mathrm{N})$ (Figure 1). The results showed that the dough hardness was partially increased by the substitution of D-psicose, while it was significantly decreased by substitution of polyol. These changes in dough hardness are particularly evident at high levels of sweetener substitution $(50 \%)$. The sugar in the biscuit formulation directly affects the formation of the gluten network by competing with the proteins for water, depending on the sugar and solubility (Gallagher et al., 2003). In this study, in the dough substituted with sorbitol and xylitol, the gluten development was inhibited because of the free 
water was absorbed by the more hygroscopic polyols, resulting in a softer dough. Accordingly, a harder biscuit dough was obtained with the less hygroscopic D-psicose substitution. Zoulias et al. (2000) reported that hardness decreased when sorbitol or xylitol were substituted in low-fat biscuit dough, while substitution with fructose and maltitol showed the opposite effect and increased dough hardness.

Table 3. Physical properties of the sweetener substituted biscuits.

\begin{tabular}{|c|c|c|c|c|c|c|c|}
\hline Samples & $\begin{array}{c}\text { Diameter } \\
(\mathrm{mm})\end{array}$ & $\begin{array}{c}\text { Thickness } \\
(\mathrm{mm})\end{array}$ & Spread ratio & $\begin{array}{l}\text { Weight } \\
(\mathrm{g})\end{array}$ & $L$ & $a$ & $b$ \\
\hline 1 & $41.52 \pm 0.17^{(\mathrm{a})}$ & $8.57 \pm 0.25$ (ab) & $4.84 \pm 0.15^{(b)}$ & $6.41 \pm 0.01^{(a)}$ & 62.85 & $10.98 \pm 0.31$ (bcd) & $23.23 \pm 0.01$ (b) \\
\hline 2 & $37.85 \pm 0.29$ (b) & $8.97 \pm 0.17(\mathrm{a})$ & $4.22 \pm 0.20^{(\mathrm{d})}$ & $6.30 \pm 0.19^{(a)}$ & $50.67 \pm 0.27(\mathrm{~g})$ & $13.52 \pm 0.41^{(\mathrm{a})}$ & $21.67 \pm 1.26^{(\mathrm{c})}$ \\
\hline 3 & $41.72 \pm 0.03^{(\mathrm{a})}$ & $8.42 \pm 0.07$ (b) & $4.95 \pm 0.04(\mathrm{a})$ & $6.50 \pm 0.23^{(a)}$ & $71.84 \pm 0.04(\mathrm{ab})$ & $9.98 \pm 0.52^{(\mathrm{d})}$ & $24.78 \pm 0.17^{(\mathrm{a})}$ \\
\hline 4 & $41.27 \pm 0$ & $8.63 \pm 0.1$ & $4.78 \pm 0.1$ & $6.47 \pm 0.20^{(a)}$ & $72.79 \pm 1.48^{(\mathrm{a})}$ & $10.68 \pm 0.02^{(\mathrm{cd})}$ & $24.87 \pm 0.27^{(a)}$ \\
\hline 5 & $41.32 \pm 0.30^{(\mathrm{a})}$ & $8.56 \pm 0.05^{(\mathrm{ab})}$ & $4.83 \pm 0.23$ (b) & $6.40 \pm 0.18^{(a)}$ & $61.29 \pm 0.38(\mathrm{ed})$ & $11.71 \pm 0.19(\mathrm{bc})$ & $23.02 \pm 0.86^{(b)}$ \\
\hline 6 & $40.77 \pm 0.88^{(a)}$ & $8.75 \pm 0.04$ (ab) & $4.66 \pm 0.53(\mathrm{c})$ & $6.39 \pm 0.43^{(a)}$ & $60.44 \pm 1.28(\mathrm{~cd})$ & $12.08 \pm 0.52^{(b)}$ & $22.26 \pm 0.82^{(\mathrm{c})}$ \\
\hline 7 & $41.92 \pm 0.22^{(\mathrm{a})}$ & $8.51 \pm 0.09$ (ab) & $4.93 \pm 0.15^{(\mathrm{a})}$ & $6.44 \pm 0.30^{(a)}$ & $69.67 \pm 1.15(\mathrm{bc})$ & $9.65 \pm 0.12^{(\mathrm{d})}$ & $24.97 \pm 0.52^{(\mathrm{a})}$ \\
\hline 8 & $40.67 \pm 0.32^{(\mathrm{a})}$ & $8.80 \pm 0.08^{(\mathrm{ab})}$ & $4.62 \pm 0.21^{(\mathrm{c})}$ & $6.32 \pm 0.43^{(a)}$ & $55.87 \pm 1.53^{(\mathrm{f})}$ & $11.84 \pm 0.40(\mathrm{bc})$ & $21.93 \pm 0.45^{(c)}$ \\
\hline 9 & $40.79 \pm 0.05^{(\mathrm{a})}$ & $8.55 \pm 0.06^{(a b)}$ & $4.77 \pm 0.02^{(\mathrm{bc})}$ & $6.43 \pm 0.21^{(\mathrm{a})}$ & $68.85 \pm 0.97(\mathrm{c})$ & $7.85 \pm 0.68^{(e)}$ & $24.66 \pm 0.19^{(\mathrm{a})}$ \\
\hline 10 & $40.83 \pm 0.05^{(\mathrm{a})}$ & $8.59 \pm 0.03$ (ab) & $4.75 \pm 0.03^{(b c)}$ & $6.44 \pm 0.49^{(a)}$ & $67.25 \pm 1.00^{(\mathrm{c})}$ & $7.67 \pm 0.81^{(\mathrm{e})}$ & $24.68 \pm 0.20^{(a)}$ \\
\hline
\end{tabular}

Different small superscripts indicate significant differences $(P<0.05)$ between biscuit samples

Adhesiveness is a parameter expressing the structural integrity of the biscuit dough. Biscuit doughs with high polyol content $(50 \%)$ showed better adhesive properties than the sample with sucrose $(100 \%)$. High adhesiveness in biscuit dough leads to technological processing problems. Therefore, the aim is to obtain a dough with lower adhesive (Mariotti and Alamprese, 2012). By substituting polyol (25\%) or D-psicose
( $25 \%$ or $50 \%)$, a dough with an adhesiveness close to the control sample was obtained (Figure 1). Yang et al. (2021) analysed doughs containing up to $5 \%$ xylitol and found an increase in adhesiveness, with a concomitant decrease in the water binding capacity of the dough and inhibition of gluten development. Similar results were reported by Mariotti and Alamprese (2012) and Zoulias et al. (2000).

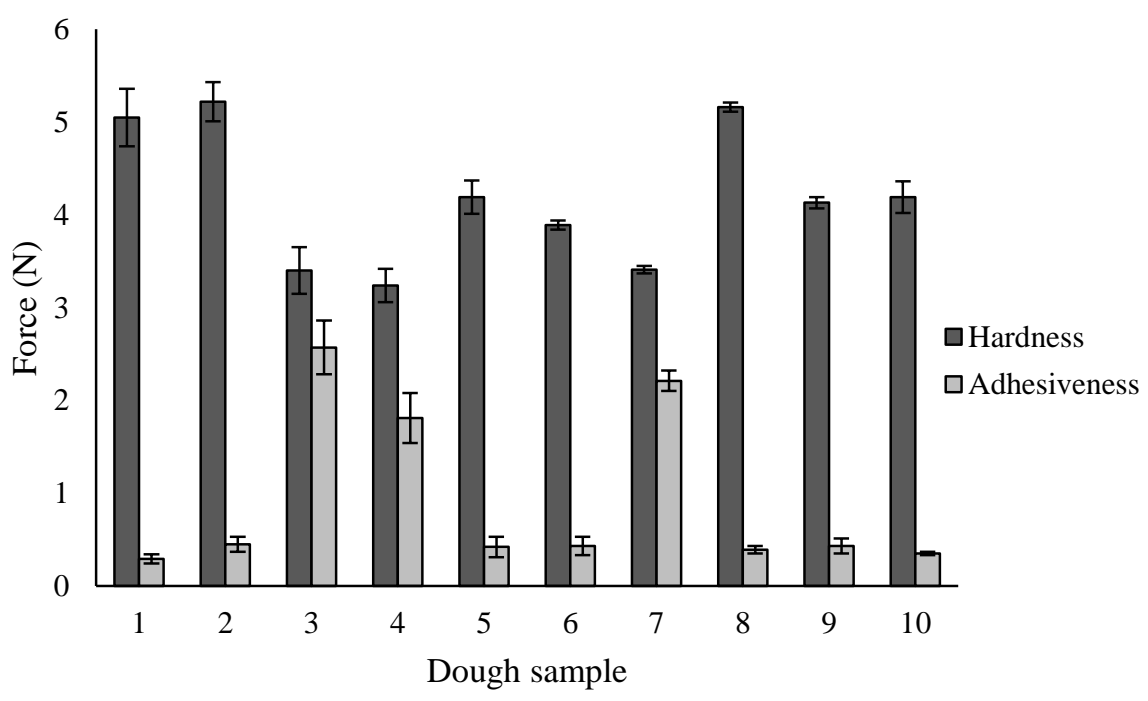

Figure 1. The hardness and adhesiveness of the sweetener substituted biscuit dough. 


\section{Textural properties of baked biscuits}

Table 4 shows the changes in hardness of biscuits during storage. It has been reported that moisture content is the most influential factor on the hardness of bakery products ( Pourfarzad et al., 2011; Ding and Yang, 2021; Park et al., 2021). Replacement of sorbitol or xylitol with sucrose results in a significant decrease in the hardness of bakery products (Zoulias et al., 2000; MartínezCervera et al., 2014; Kutyła-Kupidura et al., 2016). In a study investigating the effects of replacing Dpsicose $(10-40 \%)$ in gelatin-based soft candies, it was found that samples with higher moisture content had lower hardness values (Pocan et al., 2019). In our study, there was no statistically significant change in the hardness of the control sample with increasing storage time $(p>0.05)$, but the hardness of the biscuits with $50 \% \mathrm{D}$ psicose or polyol(s) decreased significantly $(P<0.05)$. Other results of the stored biscuits showed that the change in hardness value was insignificant for biscuits with $25 \%$ alternative sweetener. The hardness of biscuits is controlled by sugar crystallisation and availability of free water for gluten development ( Zoulias et al., 2000; Taylor et al., 2008) and water from the Maillard reaction between proteins and reducing sugars during storage (Pocan et al., 2019). Therefore, in our study, the hardness of the biscuits containing sucrose and D-psicose was the highest and the hardness of the samples containing 50\% polyol was the lowest during the storage period. In addition, moisture migration between biscuits caused the variation in the hardness value of the samples. At the end of storage, there was no significant difference between the hardness of the control and that of the biscuit with $25 \% \mathrm{D}$-psicose $(\mathrm{p}>0.05)$, while the hardness values of the samples containing polyol $(25 \%)$ and rare sugar $(25 \%)$ were close to the control.

Table 4. Hardness values of the sweetener substituted biscuits.

\begin{tabular}{|c|c|c|c|c|c|}
\hline Sample & $\begin{array}{c}\text { Hardness }(\mathrm{N}) \\
\left(1^{\text {st }} \text { day }\right)\end{array}$ & $\begin{array}{l}\text { Hardness }(\mathrm{N}) \\
\text { ( } 7^{\text {th }} \text { day) }\end{array}$ & $\begin{array}{c}\text { Hardness }(\mathrm{N}) \\
\left(15^{\text {th }} \text { day }\right)\end{array}$ & $\begin{array}{c}\text { Hardness }(\mathrm{N}) \\
\left(30^{\text {th }} \text { day }\right)\end{array}$ & $\begin{array}{c}\text { Hardness }(\mathrm{N}) \\
\left(60^{\text {th }} \text { day }\right)\end{array}$ \\
\hline 1 & $13.51 \pm 0.78(\mathrm{bc}, \mathrm{A})$ & $13.83 \pm 0.82^{(\mathrm{ab}, \mathrm{A})}$ & $14.91 \pm 1.20^{(\mathrm{a}, \mathrm{A})}$ & $14.56 \pm 0.52^{(\mathrm{a}, \mathrm{A})}$ & $15.56 \pm 0.99^{(\mathrm{a}, \mathrm{A})}$ \\
\hline 2 & $18.24 \pm 0.50^{(\mathrm{a}, \mathrm{A})}$ & $14.31 \pm 1.84(\mathrm{ab}, \mathrm{AB})$ & $15.12 \pm 1.66^{(\mathrm{a}, \mathrm{AB})}$ & $12.59 \pm 0.50^{(\mathrm{a}, \mathrm{B})}$ & $13.65 \pm 1.59$ (ab, B) \\
\hline 3 & $10.28 \pm 0.24(\mathrm{~cd}, \mathrm{~A})$ & $7.64 \pm 0.82^{(\mathrm{c}, \mathrm{AB})}$ & $6.88 \pm 0.59^{(\mathrm{c}, \mathrm{AB})}$ & $5.6 \pm 0.53^{(\mathrm{b}, \mathrm{B})}$ & $8.29 \pm 1.24(\mathrm{~d}, \mathrm{AB})$ \\
\hline 4 & $9.42 \pm 1.32^{(\mathrm{d}, \mathrm{A})}$ & $7.51 \pm 0.29(\mathrm{c}, \mathrm{B})$ & $7.66 \pm 1.03(\mathrm{c}, \mathrm{AB})$ & $7.62 \pm 0.84(\mathrm{~b}, \mathrm{AB})$ & $7.16 \pm 1.29$ (d, B) \\
\hline 5 & $13.24 \pm 1.07(\mathrm{bc}, \mathrm{A})$ & $12.38 \pm 0.51^{(\mathrm{abc}, \mathrm{A})}$ & $11.16 \pm 0.27(\mathrm{~b}, \mathrm{~A})$ & $12.68 \pm 1.59^{(\mathrm{a}, \mathrm{A})}$ & $10.25 \pm 2.12^{(\mathrm{cd}, \mathrm{A})}$ \\
\hline 6 & $12.08 \pm 0.94(\mathrm{c}, \mathrm{A})$ & $12.68 \pm 0.93(\mathrm{abc}, \mathrm{A})$ & $11.91 \pm 0.99(\mathrm{~b}, \mathrm{~A})$ & $11.45 \pm 1.22^{(\mathrm{a}, \mathrm{A})}$ & $11.82 \pm 0.55(\mathrm{bc}, \mathrm{A})$ \\
\hline 7 & $10.56 \pm 1.58^{(\mathrm{cd}, \mathrm{A})}$ & $10.41 \pm 1.68^{(\mathrm{bc}, \mathrm{A})}$ & $11.01 \pm 0.64(\mathrm{~b}, \mathrm{~A})$ & $9.85 \pm 0.69$ (ab, $A B)$ & $8.04 \pm 1.01^{(\mathrm{d}, \mathrm{B})}$ \\
\hline 8 & $17.03 \pm 1.58(\mathrm{ab}, \mathrm{A})$ & $16.01 \pm 1.97(\mathrm{a}, \mathrm{A})$ & $14.97 \pm 0.79^{(\mathrm{a}, \mathrm{A})}$ & $14.00 \pm 0.88^{(\mathrm{a}, \mathrm{A})}$ & $15.25 \pm 2.88^{(\mathrm{a}, \mathrm{A})}$ \\
\hline 9 & $13.47 \pm 1.86^{(\mathrm{cd}, \mathrm{A})}$ & $13.24 \pm 0.24(\mathrm{abc}, \mathrm{A})$ & $13.67 \pm 1.55^{(\mathrm{ab}, \mathrm{A})}$ & $11.65 \pm 0.22^{(\mathrm{a}, \mathrm{A})}$ & $11.60 \pm 0.30^{(\mathrm{ab}, \mathrm{A})}$ \\
\hline 10 & $13.75 \pm 1.56(\mathrm{~cd}, \mathrm{~A})$ & $12.75 \pm 1.99(\mathrm{abc}, \mathrm{A})$ & $12.05 \pm 1.03(\mathrm{~b}, \mathrm{~A})$ & $12.17 \pm 1.16^{(\mathrm{a}, \mathrm{A})}$ & $12.02 \pm 1.39(\mathrm{bc}, \mathrm{A})$ \\
\hline
\end{tabular}

Different small superscripts indicate significant differences $(P<0.05)$ between biscuit samples, and different capital superscripts indicate significant differences $(P<0.05)$ between measurement days

\section{Sensory properties}

Sensory evaluation is an important approach to assess food quality and can meet the needs of food manufacturers, as its parameters are used by consumers to decide "which is the best product to buy!". The effects of partial replacement of sucrose with alternative sweeteners (D-psicose, sorbitol, xylitol) on the sensory characteristics of the biscuits are shown in Table 5. Statistically, the samples with alternative sweeteners had similar taste and sweetness ratings as the control sample.
However, a significant difference was found in color, texture, and overall acceptability between the control and the other samples. Winkelhausen et al. (2007) reported that there was no significant difference in sweetness ratings between cookies with sucrose and xylitol. Similar results were reported by Martínez-Cervera et al. (2014) for muffins substituted with sorbitol. In addition, Lin et al. (2010) stated that there were no temperature-related sweetness problems in biscuits with erythritol $(50 \%)$ because polyols 
were not involved in Maillard reactions. In our study, it was found that the flavor and sweetness of the biscuits made with sorbitol and xylitol were lower compared to biscuits made with 100\% sucrose, which could be due to the lower formation of off-flavors due to temperatureinduced caramelization and browning reactions. As for color, the biscuits made by partially replacing sucrose with alternative sweeteners were rated similarly to sucrose $(100 \%)$ by the panelists, except for the sample made with 50\% D-psicose. Rare sugar resulted in a darker surface color formation in the biscuit. This is because the rare sugar that participated in Maillard reactions provided a darker surface, which can be attributed to its reducing property (Sun et al., 2004). These findings are in agreement with the studies of Taylor et al. (2008) and Lin et al. (2010). For all sweeteners, all biscuits were rated as "dislike" in terms of texture except for the $50 \%$ D-psicose samples, which were perceived by the panelists to be significantly harder and had a similar texture rating to the control biscuit. However, the sensory texture analysis was in close agreement with the instrumental measurements. As can be seen in Table 3, the replacement of D-psicose results in a harder texture, while the replacement of sucrose with polyols softens the texture significantly. In terms of overall acceptability, no statistical difference was found between the control and the other biscuits, except for the sample replaced by D-psicose $(50 \%)$, which had the highest value (3.27 \pm 1.05$)$. In addition, it was found that the sweetness perception of the panelist was the most reliable factor to evaluate the overall acceptability of the biscuits $\left(\mathrm{R}^{2}=0.79\right.$, data not shown). Similar findings were reported by Martínez-Cervera et al. (2014) for the sorbitol substituted muffins.

Table 5. Sensory properties of the sweetener substituted biscuits.

\begin{tabular}{|c|c|c|c|c|c|}
\hline Sample & Color & Flavor & Sweetness & Texture & Overall acceptability \\
\hline 1 & $3.23 \pm 0.86^{(a)}$ & $2.97 \pm 0.90^{(\mathrm{a})}$ & $3.07 \pm 1.05^{(a)}$ & $3.07 \pm 1.17^{(a)}$ & $3.10 \pm 0.84^{(\mathrm{ab})}$ \\
\hline 2 & $2.56 \pm 0.81^{(b)}$ & $3.13 \pm 1.14^{(a)}$ & $3.23 \pm 1.19^{(a)}$ & $3.03 \pm 1.00^{(a)}$ & $3.27 \pm 1.05^{(\mathrm{a})}$ \\
\hline 3 & $2.86 \pm 0.78^{(\mathrm{ab})}$ & $2.93 \pm 0.78^{(a)}$ & $2.93 \pm 1.11^{(\mathrm{a})}$ & $2.77 \pm 0.97(\mathrm{ab})$ & $2.90 \pm 0.80^{(\mathrm{ab})}$ \\
\hline 4 & $2.86 \pm 0.90^{(\mathrm{ab})}$ & $2.67 \pm 0.71^{(\mathrm{a})}$ & $2.70 \pm 0.95^{(a)}$ & $2.70 \pm 1.02^{(\mathrm{ab})}$ & $2.83 \pm 0.75$ (ab) \\
\hline 5 & $2.80 \pm 0.97(\mathrm{ab})$ & $3.17 \pm 1.18^{(a)}$ & $2.80 \pm 0.97^{(a)}$ & $2.17 \pm 1.02^{(b)}$ & $2.70 \pm 1.06^{(\mathrm{ab})}$ \\
\hline 6 & $2.83 \pm 1.05^{(\mathrm{ab})}$ & $3.20 \pm 0.87^{(a)}$ & $3.13 \pm 1.01^{(a)}$ & $2.77 \pm 0.90^{(\mathrm{ab})}$ & $2.90 \pm 0.84^{(\mathrm{ab})}$ \\
\hline 7 & $3.06 \pm 0.94(\mathrm{ab})$ & $2.77 \pm 0.90^{(a)}$ & $2.57 \pm 0.94(\mathrm{a})$ & $2.57 \pm 1.07(\mathrm{ab})$ & $2.67 \pm 0.80^{(\mathrm{ab})}$ \\
\hline 8 & $2.76 \pm 1.01^{(\mathrm{ab})}$ & $2.93 \pm 0.91^{(\mathrm{a})}$ & $2.47 \pm 1.01^{(\mathrm{a})}$ & $2.23 \pm 0.90^{(\mathrm{ab})}$ & $2.57 \pm 0.86^{(\mathrm{ab})}$ \\
\hline 9 & $3.03 \pm 1.04$ (ab) & $2.87 \pm 0.78^{(a)}$ & $2.57 \pm 0.86^{(a)}$ & $2.37 \pm 0.85^{(\mathrm{ab})}$ & $2.73 \pm 0.78$ (ab) \\
\hline 10 & $2.80 \pm 0.71^{(\mathrm{ab})}$ & $2.93 \pm 0.64^{(a)}$ & $2.57 \pm 1.01^{(\mathrm{a})}$ & $2.67 \pm 0.96(\mathrm{ab})$ & $2.67 \pm 0.71$ (ab) \\
\hline
\end{tabular}

Different small superscripts indicate significant differences $(P<0.05)$ between biscuit samples

\section{CONCLUSION}

The present study has shown that D-psicose, sorbitol and xylitol individually or with their mixtures can produce biscuits that are acceptable in terms of physicochemical, textural and sensory aspects. Partial substitution of sucrose with Dpsicose in the biscuits resulted in a significant increase in thickness and hardness compared to the control. Moreover, increasing D-psicose substitution resulted in lower spread ratio and Hunter $\mathrm{L}$ values. On the other hand, increasing substitution of polyol(s) in the biscuits had the opposite effect. Thus, there was a decrease in highness and hardness values and an increase in spreadability and Hunter L values. However, in general, D-psicose improved the dough properties of biscuits, while sorbitol and xylitol negatively affected the dough quality. It was concluded that significant improvement in biscuit properties can be achieved by the substitution of sucrose with D-psicose and polyol(s) within certain limits.

\section{ACKNOWLEDGMENTS}

This study was supported by the Research Project Unit of Pamukkale University (Project No:2013FBE023)

\section{CONFLICT OF INTEREST}

The author(s) declares no conflict of interest 


\section{AUTHORS CONTRIBUTIONS}

Mehmet GÜLDANE performed investigation, methodology, formal analysis, writing, editing and original draft. Emine Nur HERKEN was supervisor and administrated the project.

\section{REFERENCES}

AACC. (1990). Approved Methods of American Association of Cereal Chemists. 8th Edition, St. Paul, the USA.

Chevallier, S., Colonna, P., Della Valle, G., Lourdin, D. (2000). Contribution of major ingredients during baking of biscuit dough systems. J Cereal Sci, 31(3): 241-252, doi: 10.1006/jcrs.2000.0308.

Davis, E.A. (1995). Functionality of sugars: Physicochemical interactions in foods. Am J Clinical Nutr, 62(1): 170-177, doi:10.1093/ ajcn/62.1.170S.

Ding, S., Yang, J. (2021). The effects of sugar alcohols on rheological properties, functionalities, and texture in baked products - A review. Trends in Food Sci \& Techno, 111: 670-679, doi:10.1016/ j.tifs.2021.03.009.

Drewnowski, A., Nordensten, K., Dwyer, J. (1998). Replacing sugar and fat in cookies: Impact on product quality and preference. Food Quality and Preference, 9(1-2): 13-20, doi:10.1016/s09503293(97)00017-7.

Edwards, C.H., Rossi, M., Corpe, C.P., Butterworth, P.J., Ellis, P.R. (2016). The role of sugars and sweeteners in food, diet and health: Alternatives for the future. Trends in Food Sci \& Techn, 56: 158-166, doi:10.1016/j.tifs.2016.07.008.

Fasahat, P., Aghaeezadeh, M., Hosseinpour, M., Sadeghzadeh H.S. (2021). Correlation between root weight and sugar content; do we have to continue traditional hypothesis? Plant Physiology Reports, 26(1): 188-191, doi:10.1007/s40502-02000560-2.

Gallagher, E., O'Brien, C.M., Scannell, A.G.M., Arendt, E.K. (2003). Evaluation of sugar replacers in short dough biscuit production. J Food Eng 56(2-3): 261-263, doi:10.1016/S02608774(02)00267-4.
Ghosh, S., Sudha, M.L. (2012). A review on polyols: New frontiers for health-based bakery products. Int J Food Sci and Nutr, 63(3): 372-379, doi:10.3109/09637486.2011.627846.

Granström, T.B., Takata, G., Tokuda, M., Izumori, K. (2004). Izumoring: A novel and complete strategy for bioproduction of rare sugars. J Bioscience and Bioengineering, 97(2): 89-94, doi:10.1263/jbb.97.89.

Gül, H., Yanik, A., Acun, S. (2013). Effects of white cabbage powder on cookie quality. $J$ Food, Agr Environ, 11(1): 68-72.

Herken, E.N., Simsek, S., Ohm, J.B., Yurdunuseven, A. (2017). Effect of Mahaleb on Cookie Quality. J Food Processing and Preservation, 41(4): 1-13, doi:10.1111/jfpp.13032.

Ho, L.H., Pulsawat, M.M. (2020). Effects of partial sugar replacement on the physicochemical and sensory properties of low sugar cookies. Int Food Research J, 27(3): 557-567.

Hsu, H.W., Vavak, D.L., Satterlee, L.D., Miller, G.A. (1977). A Multienzyme Technique for Estimating Protein Digestibility. J Food Sci, 42(5): 1269-1273, doi:10.1111/j.13652621.1977.tb14476.x.

Karp, S., Wyrwisz, J., Kurek, M., Wierzbicka, A. (2016). Physical properties of muffins sweetened with steviol glycosides as the sucrose replacement. Food Sci and Biotechnology, 25(6): 1591-1596, doi:10.1007/s10068-016-0245-x.

Kroger, M., Meister, K., Kava, R. (2006). Lowcalorie sweeteners and other sugar substitutes: A review of the safety issues. Comprehensive Reviens in Food Sci and Food Safety, 5(2): 35-47, doi:10.1111/j.1541-4337.2006.tb00081.x.

Kutyła-Kupidura, E.M., Sikora, M., Krystyjan, M., Dobosz, A., Kowalski, S., Pysz, M., Tomasik, P. (2016). Properties of Sugar-Free Cookies with Xylitol, Sucralose, Acesulfame K and Their Blends. J Food Process Eng, 39(4): 321-329, doi:10.1111/jfpe.12222.

Kweon, M., Slade, L., Levine, H. (2016). Potential sugar reduction in cookies formulated with sucrose alternatives. Cereal Chem, 93(6): 576-583, doi:10.1094/CCHEM-01-16-0016-R. 
Laguna, L., Vallons, K.J.R., Jurgens, A., Sanz, T. (2013). Understanding the Effect of Sugar and Sugar Replacement in Short Dough Biscuits. Food and Bioprocess Techn, 6(11): 3143-3154, doi:10.1007/s11947-012-0968-5.

Lin, S.D., Lee, C.C., Mau, J.L., Lin, L.Y., Chiou, S.Y. (2010). Effect of erythritol on quality characteristics of reduced-calorie danish cookies. $J$ Food Quality, 33(1): 14-26, doi:10.1111/j.17454557.2010.00307.x.

Majeed, M., Mahmood, M.A., Khan, M.U., Fazel, M., Shariati, M.A., Pigorev, I. (2018). Effect of sorbitol on dough rheology and quality of sugar replaced cookies. Potravinarstuo Slovak J of Food Sci, 12(1): 50-56, doi:10.5219/709.

Mariotti, M., Alamprese, C. (2012). About the use of different sweeteners in baked goods. Influence on the mechanical and rheological properties of the doughs. LWT - Food Science and Technology, 48(1): 9-15, doi:10.1016/j.lwt.2012.03.001.

Martínez-Cervera, S., Salvador, A., Sanz, T. (2014). Comparison of different polyols as total sucrose replacers in muffins: Thermal, rheological, texture and acceptability properties. Food Hydrocolloids, 35: 1-8, doi:10.1016/ j.foodhyd.2013.07.016.

Miller, R.A., Hoseney, R.C. (1997). Factors in hard wheat flour responsible for reduced cookie spread. Cereal Chem, 74(3): 330-336, doi:10.1094/ CCHEM.1997.74.3.330.

Mooradian, A.D., Smith, M., Tokuda, M. (2017). The role of artificial and natural sweeteners in reducing the consumption of table sugar: A narrative review. Clinical Nutr ESPEN, 18: 1-8, doi:10.1016/j.clnesp.2017.01.004.

Pareyt, B., Talhaoui, F., Kerckhofs, G., Brijs, K., Goesaert, H., Wevers, M., Delcour, J.A. (2009). The role of sugar and fat in sugar-snap cookies: Structural and textural properties. J Food Eng 90(3): $\quad 400-408, \quad$ doi:10.1016/j.jfoodeng. 2008.07.010.

Park, H.R., Kim, G.H., Na, Y., Oh, J.E., Cho, M.S. (2021). Physicochemical and sensory properties of protein-fortified cookies according to the ratio of isolated soy protein to whey protein. Food Sci Biotechnology, 30(5): 653-661, doi:10.1007/s10068-021-00909-9.

Pocan, P., Ilhan, E., Oztop, M.H. (2019). Effect of d-psicose substitution on gelatin based soft candies: A TD-NMR study. Magnetic Resonance in Chem, 57(9): 661-673, doi:10.1002/mrc.4847.

Pourfarzad, A., Khodaparast, M.H.H., Karimi, M., Mortazavi, S.A., Davoodi, M.G., Sourki, A. H., Razavizadegan Jahromi, S.H. (2011). Effect of polyols on shelf-life and quality of flat bread fortified with soy flour. J Food Process Eng, 34(5): 1435-1448, doi:10.1111/j.1745-4530.2009. 00541.x.

Schroeder, K., Schuler, B.R., Kobulsky, J.M., Sarwer, D.B. (2021). The association between adverse childhood experiences and childhood obesity: A systematic review. Obesity Reviews, 22(7): 1-18, doi:10.1111/obr.13204.

Struck, S., Jaros, D., Brennan, C.S., Rohm, H. (2014). Sugar replacement in sweetened bakery goods. Int J Food Sci and Technology, 49(9): 19631976, doi:10.1111/ijfs.12617.

Sun, Y., Hayakawa, S., Izumori, K. (2004). Modification of Ovalbumin with a Rare Ketohexose through the Maillard Reaction: Effect on Protein Structure and Gel Properties. Journal of Agricultural and Food Chem, 52(5): 12931299, doi:10.1021/jf030428s.

Taylor, T.P., Fasina, O., Bell, L.N. (2008). Physical properties and consumer liking of cookies prepared by replacing sucrose with tagatose. J Food Sci, 73(3): 145-151, doi:10.1111/ j.1750-3841.2007.00653.x.

Vatankhah, M., Garavand, F., Elhamirad, A., Yaghbani, M. (2015). Influence of sugar replacement by stevioside on physicochemical and sensory properties of biscuit. Quality Assurance and Safety of Crops and Foods, 7(3): 393-400, doi:10.3920/QAS2014.0396.

Winkelhausen, E., Jovanovic-Malinovska, R., Velickova, E., Kuzmanova, S. (2007). Sensory and Microbiological Quality of a Baked Product Containing Xylitol as an Alternative Sweetener. Int J Food Properties, 10(3): 639-649, doi:10.1080/10942910601098031. 
Yang, H., Fu, Y., Zhang, Y., Zhou, J., Wang, D., Gao, Z., Ke, Y., Lv, Q., Ding, B., Wang, X. (2021). Evaluation of mannitol and xylitol on the quality of wheat flour and extruded flour products. Int J Food Sci Techn, 56: 4119-4128, doi:10.1111/ijfs.15040.

Zoulias, E.I., Piknis, S., Oreopoulou, V. (2000). Effect of sugar replacement by polyols and
acesulfame-K on properties of low-fat cookies. $J$ Sci Food Agr, 80(14): 2049-2056, doi:10.1002/ 1097-0010(200011)80:14<2049: AID-JSFA735> 3.0.CO;2-Q. 